\title{
Knowledge about antineoplastic drugs: implications for the health of nursing workers in a general hospital
}

\author{
Conhecimentos sobre drogas antineoplásicas: implicações para a saúde do trabalhador de enfermagem em hospital geral
}

Conocimientos acerca de las drogas antineoplásicas: implicaciones a la salud del trabajador de enfermería en hospital general

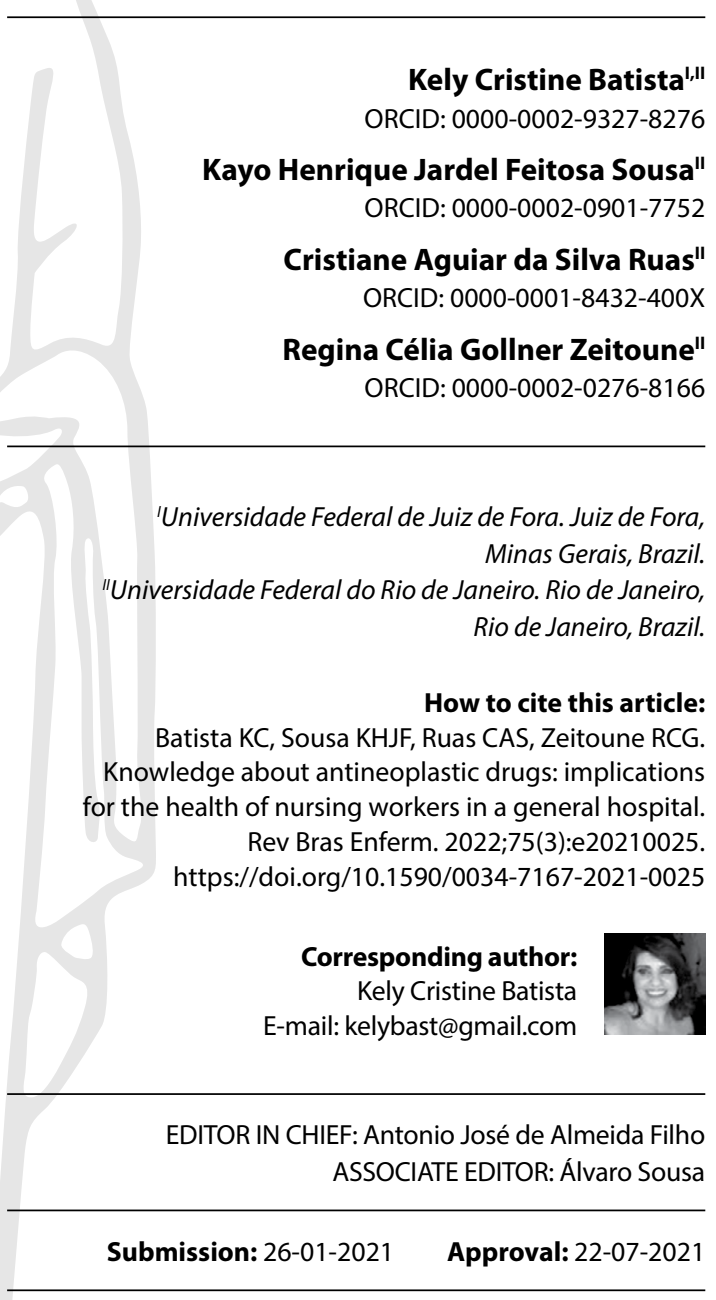

\section{ABSTRACT}

Objectives: to understand, from a worker's health perspective, the knowledge of nursing professionals about the use of antineoplastic drugs in a general hospital. Methods: a descriptive and exploratory study with a qualitative approach. It was conducted at a university hospital, between April and August 2018, with 35 nursing professionals who responded to a semi-structured interview. Thematic analysis was used for data treatment. Results: from the data, three thematic categories emerged, related to the nursing professionals'knowledge about antineoplastic drugs and their effects on workers' health; situations in which exposure to these drugs occurs; and protection mechanisms for the patient, the environment, and the worker. Final Considerations: the nursing professionals had little knowledge about antineoplastic drugs. The practices related to handling and the necessary protective measures to deal with these drugs were empirically determined and relatively subsidized the knowledge acquired by the professionals.

Descriptors: Nursing; Antineoplastics Agents; Occupational Health; General Hospitals; Oncology Nursing.

\section{RESUMO}

Objetivos: compreender, na perspectiva da saúde do trabalhador, os conhecimentos dos profissionais de enfermagem sobre a utilização de drogas antineoplásicas em um hospital geral. Métodos: estudo descritivo e exploratório com abordagem qualitativa. Foi realizado em um hospital universitário, entre abril e agosto de 2018 , com 35 profissionais de enfermagem que responderam a uma entrevista semiestruturada. Utilizou-se a análise temática para o tratamento dos dados. Resultados: emergiram, dos dados, três categorias temáticas relacionadas aos conhecimentos dos profissionais de enfermagem sobre drogas antineoplásicas e seus efeitos para a saúde do trabalhador; situações em que ocorre a exposição a essas drogas; $\mathrm{e}$ mecanismos de proteção ao paciente, ao meio ambiente e ao trabalhador. Considerações Finais: os profissionais de enfermagem apresentavam pouco conhecimento sobre as drogas antineoplásicas. As práticas relacionadas ao manuseio e as medidas de proteção necessárias para lidar com essas drogas eram empiricamente determinadas e subsidiavam relativamente o conhecimento adquirido pelos profissionais.

Descritores: Enfermagem; Antineoplásicos; Saúde do Trabalhador; Hospitais Gerais; Enfermagem Oncológica.

\section{RESUMEN}

Objetivos: comprender, en la perspectiva de salud del trabajador, los conocimientos de los profesionales de enfermería sobre la utilización de drogas antineoplásicas en un hospital general. Métodos: estudio descriptivo y exploratorio con abordaje cualitativo. Realizado en un hospital universitario, entre abril y agosto de 2018 , con 35 profesionales de enfermería que respondieron una entrevista semiestructurada. Utilizado el análisis temático para el tratamiento de datos. Resultados: emergieron, de los datos, tres categorías temáticas relacionadas a conocimientos de los profesionales de enfermería sobre drogas antineoplásicas y sus efectos para la salud del trabajador; situaciones en que ocurre la exposición a esas drogas; y mecanismos de protección al paciente, medio ambiente y trabajador. Consideraciones Finales: los profesionales de enfermería presentaban poco conocimiento sobre las drogas antineoplásicas. Las prácticas relacionadas al manejo y medidas de protección necesarias para lidiar con esas drogas eran empíricamente determinadas y subsidiaban relativamente el conocimiento adquirido por los profesionales. Descriptores: Enfermería; Antineoplásicos; Salud Laboral; Hospitales Generales; Enfermería Oncológica. 


\section{INTRODUCTION}

Cancer is a global public health problem, being one of the main causes of morbidity and mortality in the world. The incidence of cancer in Brazil for the triennium 2020-2022, according to the National Cancer Institute (INCA), reflected the general trend of increasing cases: about 625 thousand for each year ${ }^{(1)}$. The increase in the incidence of cancer has led to an increase in the use of antineoplastic drugs for its treatment and/or control(1-2).

Antineoplastic drugs are toxic to any tissue, proliferate rapidly and have as characteristics high mitotic activity and short cell cycles, whether normal or cancerous ${ }^{(3)}$. They have carcinogenic, teratogenic and genotoxic properties, even at low doses, and are classified as hazardous drugs (HD), a group that includes other drugs such as ganciclovir, zidovudine and risperidone ${ }^{(4-5)}$.

Given the risks presented both to patients and to the health of the workers who handle them, these drugs have been growing focuses of investigation. Due to reproductive toxicity, these professionals may, for example, be subject to spontaneous abortions, temporary or permanent infertility, and premature births, with the possibility of damage also to their children, such as congenital malformations, learning deficits, deoxyribonucleic acid (DNA) and chromosome abnormalities, and the occurrence of cancer ${ }^{(6-7)}$.

The care for patients who use antineoplastic drugs is not restricted to the reference institutions for cancer treatment ${ }^{(8-9)}$ and is being carried out at all levels of health care by trained or untrained professionals ${ }^{(10)}$. Based on the professional practice, it was observed that patients referred to the general hospital, the setting of this study, for treatment of clinical situations such as diabetes, heart, kidney, rheumatologic pathologies, among others, often have associated with their clinical picture stories of cancer or autoimmune diseases, which require the use of antineoplastic drugs.

This is a frequent reality, bringing concerns about the health workers and to the nursing staff since it is characterized as another work demand for these professionals. They are not always prepared to deal with this specific situation, which can lead them to be exposed to the health risks inherent to such drugs ${ }^{(9)}$.

In Brazil, the Collegiate Directive Resolution (CDR) No. 220, of September 21, 2004, of the National Health Surveillance Agency (ANVISA), establishes the technical regulations for the operation of antineoplastic therapy services. It is the only standardization in force that designates the care to be performed with these drugs and the personal protection equipment (PPE) that must be used for worker protection ${ }^{(4)}$. Thus, to ensure safety in the workplace, effective communication between professionals and the institution is necessary, where there is trust, systematization of organizational learning and fostering of collective commitment to mitigate risks and damage to workers' health.

In nursing, the experience of professionals is often attributed to the time they have spent handling antineoplastic drugs ${ }^{(11)}$, essential factor to be prioritized and analyzed by institutions regarding this activity. It is important to highlight, however, that the time of work in these services does not legitimize that these professionals use and know about the importance of the necessary equipment, perform safe administration and disposal of these drugs, are aware of the side and adverse effects and realize where and how vulnerable they are to the occurrence of exposure ${ }^{(9,11)}$.
A bibliographic survey in the databases Latin American and Caribbean Literature on Health Sciences (LILACS) and National Library of Medicine (PubMed/MEDLINE), at the time this study was conceived, returned nine articles that identified the knowledge of nursing professionals about antineoplastic drugs, only one of which was carried out in a general hospital. Thus, it is worth mentioning that there may be gaps in the knowledge of nursing professionals and their actual behavior regarding the potential risks of antineoplastic drugs, since it was found, in the databases searched, a scarcity of literature addressing the theme.

Added to the gap in scientific production about the knowledge about antineoplastic drugs of nursing professionals from general hospitals, there is also the lack of acquisition of "patient and professional safety awareness" ${ }^{\prime \prime(10)}$ through continuing education supported this research. When discussing safety culture, which involves a set of shared beliefs that support safe practices, it is worth noting that it is a primordial strategy for ensuring quality care, by training professionals, making safety equipment available, establishing protocols and notification flows, and organizational measures $^{(12)}$.

Thus, professionals should be encouraged to reflect, in a permanent way, about the reality experienced contemplating a broad view of antineoplastic drugs, a fundamental point for the articulation between theoretical knowledge and qualification of protective practices, seeking tools and means for the safe handling of these drugs. In this context, the present study was guided by the question: What is the knowledge of nursing professionals working in a general hospital about antineoplastic drugs and their interface with workers' health?

\section{OBJECTIVES}

To understand, from a worker's health perspective, the knowledge of nursing professionals about the use of antineoplastic drugs in a general hospital.

\section{METHODS}

\section{Ethical aspects}

The research complied with the ethical precepts for research involving human beings. To ensure anonymity, the participants were named by alphanumeric codes: initial of the professional category, followed by a number indicating the order of insertion in the research.

\section{Type of study}

This is a descriptive and exploratory study with a qualitative approach. The Consolidated Criteria for Reporting Qualitative Research (COREQ) checklist was used as a guiding tool for this article.

\section{Study scenario}

The study site was a federal university hospital located in the Southeast Region of Brazil. The unit has inpatient and outpatient services and a Psychosocial Care Center. The present investigation 
took place in the medical, surgical, and pediatric clinical sectors and in the Intensive Care Unit (ICU). The choice of these locations was intentional and occurred because they are where the administration of antineoplastic drugs occasionally occurs, based on the needs of patients, not being, however, specific sectors for cancer treatment.

\section{Data sources}

The study participants were defined considering all nursing professionals working in the referred sectors, regardless of the type of employment relationship. Professionals with any kind of leave during the data collection period were excluded, as well as those who were covering vacations, leaves and/or absences and who were not original from the selected sectors.

The capture of the participants was done by the snowball technique, according to which a key informant indicates another potential participant, and so on, until the objective of the investigation is reached. The use of this technique was necessary because the participants were workers with little availability for activities related to the research. The key informants were randomly selected, one for each sector. When the indicated professional could not be found after three attempts, a new indication was requested. One professional refused to participate, so a new appointment was requested. The sample included 35 professionals, 23 nursing technicians and 12 nurses.

\section{Data collection}

Data collection occurred between April and August 2018, through individual interviews, guided by a semi-structured script with questions for sociodemographic and labor characterization and questions related to the object of investigation: "Talk about what you know about antineoplastic drugs"; "In the hospital environment, discuss in which situations exposure to antineoplastic drugs can occur"; and "Talk about your experience in handling antineoplastic drugs". It is noteworthy that the research instrument was not submitted to pilot-testing with the target population, however it was referenced for use by two university professors with expertise in oncologic care and workers' health.

The main researcher - experienced in handling antineoplastic drugs and an employee of the researched institution - went to the sectors and consulted the possible participants about their interest in contributing to the investigation. The interviews were scheduled according to the guest's availability and, when necessary, rescheduled, taking place in places inside the institution that guaranteed the participant's privacy and no interruption. The interviews were recorded and lasted between 60 and 120 minutes. There was no need to repeat the interviews, because the recordings presented good audio quality and met the study's objective. For the interruption of data collection, the criterion adopted was the recurrence of the speeches.

\section{Data organization and analysis}

Data was analyzed using the thematic content analysis technique ${ }^{(13)}$, without the aid of software. Initially, the interviews were transcribed and organized, establishing a text corpus that was subjected to floating reading by the main researcher to identify typing errors and approximate the themes evoked. We proceeded with the marking of the registration units $(\mathrm{RU})$ - themes - which were grouped into significance units (SU) by proximity of content, analyzed later in quantitative and qualitative terms, which subsidized the identification of the thematic categories. Data interpretation considered the confrontation with the already disseminated and normative scientific knowledge regarding the management of antineoplastic drugs.

\section{RESULTS}

Among the 35 nursing professionals participating in the study, most were female $(65.71 \%, \mathrm{n}=23)$; married $(65.71 \% \mathrm{n}=23)$; had a lato sensu specialization $(51.43 \%, \mathrm{n}=18)$; had a contractual work regime $(57 \%, n=20)$ - that is, work relations were governed by the Consolidation of Labor Laws (CLT) -; were on duty in a 12/36 hours or $12 / 60$ hours work schedule $(80 \%, n=28)$; had a workload of 40 hours a week $(42.86 \%, n=16)$; performed their functions at night $(68.57 \%, n=24)$; and had a job $(65.71 \%, n=23)$. As for the time of work in the hospital, there was a predominance for the period of up to five years $(51 \%, n=18)$ and for the time of work in the same sector between one and five years $(51.43 \%, \mathrm{n}=18)$.

Regarding the experience with antineoplastic drugs, 17 (48.57\%) answered affirmatively, eight (22.85\%) had never had contact, and another ten $(28.57 \%)$ informed that, if they had ever handled them, it was without knowing that this group of drugs was involved. Regarding the ability to handle and administer antineoplastic drugs, $32(91 \%)$ showed a limitation to perform this activity. Regarding the knowledge related to antineoplastic drugs, five (14.28\%) answered negatively, and seven (20\%) could not say what were the effects of these drugs on patients, environment and/or workers.

Through thematic content analysis, three empirical categories were identified, described as follows.

\section{Nursing professionals' knowledge about antineoplastic drugs and their effects on workers' health}

Table 1 presents the RUs that make up Category 1. The RUs in this category revealed the division of the themes into two subcategories, which deal with the knowledge about the indications for the use of antineoplastic drugs and their effects on the worker's health.

The participants'reports show little knowledge about antineoplastic drugs. It is noteworthy, however, that some professionals knew their action in fighting malignant cells.

Antineoplastic drugs are drugs that have great toxicity [...] they interrupt cell reproduction and destroy both good and cancerous cells, they do not have a selection for the cancer cell [...]. (E5)

[...] are strong drugs that decrease the immunity of the patients; and, for the health care professional, reactions may occur, but I don't know which ones. (E9)

[...] I don't know the drugs. And the only thing that I have heard about, sometimes seeing some videos on YouTube, or even a relative that has used them, is that the drug tries to act on the cell that has cancer, but it is a bombardment. It tries to attack, but it ends up attacking a lot of good cells too [...]. (T11) 
Chart 1 - Nursing professionals' knowledge about antineoplastic drugs and their effects on workers' health

\begin{tabular}{|c|c|c|c|c|}
\hline Registration Unit & Quantification & $\%$ & Subcategories & Category \\
\hline Used for cancer treatment & 17 & 48.57 & \multirow{4}{*}{$\begin{array}{l}\text { Knowledge of nursing } \\
\text { professionals about the } \\
\text { indications for use of } \\
\text { antineoplastic drugs }\end{array}$} & \multirow{10}{*}{$\begin{array}{l}\text { Nursing professionals' } \\
\text { knowledge about } \\
\text { antineoplastic drugs and } \\
\text { their effects on workers' } \\
\text { health }\end{array}$} \\
\hline Interrupt the cellular reproduction of cancer cells & 8 & 22.85 & & \\
\hline No knowledge about the drugs & 5 & 14.28 & & \\
\hline They are drugs used for diseases other than cancer & 3 & 8.57 & & \\
\hline Skin, mucous membrane and eye irritation & 13 & 37.14 & \multirow{6}{*}{$\begin{array}{l}\text { Knowledge of nursing } \\
\text { professionals about the } \\
\text { effects of antineoplastic } \\
\text { drugs on the worker's health }\end{array}$} & \\
\hline Respiratory and airway problems & 8 & 22.86 & & \\
\hline Doesn't know the effects & 7 & 20.00 & & \\
\hline Can cause cancer & 4 & 11.43 & & \\
\hline Infertility, birth defects, abortion & 3 & 8.57 & & \\
\hline Drugs that decrease the professional's immunity & 2 & 5.71 & & \\
\hline
\end{tabular}

They are drugs that fight cancer, but also fight the individual's cells, the body's defense cells, the good cells. (T18)

I only know that they are used for cancer. They target the cancer cells and work on the whole body. They are dangerous drugs, but I can't tell you why. (T29)

Moreover, other reports demonstrate knowledge about the use of these drugs for other pathologies.

Antineoplastic drugs are drugs used for the treatment of cancer, but also for other types of treatment, such as autoimmune diseases. And there are others, but now I can't remember. (E2)

Basically, what I know is that they are used for cancer patients and are used for some diseases other than cancer. (E5)

Normally, in the [...] sectors, the use of antineoplastic drugs is not daily. There it is used for pulse therapy. (T14)

\section{Nursing professionals' knowledge about situations in which exposure to antineoplastic drugs occurs}

About the situations of exposure to antineoplastic drugs, it was possible to identify four RUs that present moments of professional nursing practice in which professionals may be exposed to these drugs, from the participants' perspective, as shown in Chart 2.

For the nursing staff investigated, the situations of greatest exposure to antineoplastic drugs are in the actual administration and disposal, as well as when caring for patients who use these drugs:
At the time of drug administration, you can run the risk of exposure. When you are going to administer to the patient, when you turn on the access, drops of medication can fall on the professional. (E2)

I have experience, not much, but eventually I must do these drugs in my sector. They are done intravenously. (E8)

Contamination during administration can occur if there is a disconnection of the access equipment, and this can lead to drops of the drug falling on the professional or on the bed linen. (T12)

The experience I've had is that of administering, withdrawing and discarding. (T13)

On the other hand, the professionals ponder that they do not know how to identify other situations of exposure through contact with drugs, mainly because they do not recognize which drugs are classified as antineoplastic, according to the following reports:

I think I once saw a patient who was using antineoplastic drugs [...], but now I don't remember the name of the drug. (E3)

As far as I know, I had no contact, I don't know the names. But there was a situation that happened here in the hospital: the professionals of a sector asked for an opinion about a medication that was a chemotherapy, about how to handle and administer it, so we went to find out, and in fact nobody had the orientation, preparation, and training to guide. (E6)

If I handled any of them, I don't know, because I don't know their names. (T7)

Chart 2 - Nursing professionals' knowledge about situations in which exposure to antineoplastic drugs occurs

\begin{tabular}{|l|c|c|c|}
\hline Registration Unit & Quantification & $\%$ & Categoria \\
\hline Handling contaminated excreta and/or clothing & 2 & 5.71 & \\
\hline In drug preparation, due to bottle breakage & 9 & 25.71 & $\begin{array}{l}\text { Nursing professionals' } \\
\text { knowledge about situations } \\
\text { in which exposure to } \\
\text { antineoplastic drugs occurs }\end{array}$ \\
\hline $\begin{array}{l}\text { At drug disposal, with release and aspiration of drug particles and/or fall on } \\
\text { professional }\end{array}$ & 22 & 62.86 \\
\hline $\begin{array}{l}\text { At drug administration, through disconnection of the puncture device, loss of access, } \\
\text { vial rupture and/or rupture of the infusion lines }\end{array}$ & 35 & 100.0 & \\
\hline
\end{tabular}


Here in the hospital, we handled it, not knowing the risks we were running. (T14)

Many times, leven did it, but I didn't even know what I was doing. Sometimes, after we had already done it, someone would come along and say: Ah, this is chemotherapy. (T15)

Regarding the effects of antineoplastic drugs on workers' health, the professionals showed superficial knowledge, permeated by doubts and uncertainties:

Some hematological disease. I don't know much, no. I don't know if it is skin lesion, where an inflammatory reaction can occur if he has a loss of continuity in the skin. And the inhalation issue, would it be during manipulation for those who prepare. (E1)

In women, for example, it can cause teratogenic effects, it can cause miscarriage and lower hemoglobin and red blood cell counts. It can even lead to anemia in exposed workers. (E2)

A cellular modification, which can even lead to cancer. And if it falls on the skin, it can cause a burn, maybe a mild burn, a hyperemia, a change in the skin. (E3)

In contact with the skin, they can cause irritation in the professional; if they fall on the mucous membrane, it can be aggressive, it can cause an irritation or even something more serious, depending on where it is. [...] they may have respiratory problems like irritation, coughing, some dermatitis, when the drug comes in contact with the skin. I think that is it. (T5)

[...] / imagine, I deduce that it must go there in the immune system, it must disturb something, give a drop of immunity, I think it must be that, but I don't know. (T12)

[...], but I think it can also damage the cells of the worker who was exposed, even causing cancer, without him knowing. (T15)

I think it can cause a cellular alteration, provoking a cancer even. (T17)

\section{Nursing professionals' knowledge about patient, environ- ment, and worker protection mechanisms}

Table 3 presents the RUs related to the knowledge of nursing professionals of the hospital investigated about the safety measures to be adopted for the protection of the patient, the environment, and the worker. It is noteworthy that all participants recognized measures to be adopted for patient protection, as well as the need for the worker to use PPE, being the practices for environmental protection related to the correct disposal of clothing and materials exposed to antineoplastic drugs.

The participants reported little practice in handling antineoplastic drugs at the institution. It is noteworthy that doubts related to the procedures necessary to protect the patient, the environment and themselves were perceived in their reports. It was also possible to verify in their statements some aspects pointed out as safety measures that have interfaces among the three dimensions mentioned, that is, patient, environment and professional.

Regarding patient protection, these were the reports:
In venous access, it is to see hyperemia, pay attention to the patient's complaint, local edema, especially in accesses of vesicant medications, because they can cause necrosis. This is a caution, because it can cause damage to the patient; and, when changing medication, you always must observe the right route. (E4)

And if there is infiltration, it is also advisable to use cold compresses on the site. In some medications, and there are also medications that the patient cannot put his hand in cold water, only in warm water. (T13)

I think it is in the administration itself, it is to have a correct, patent venous access, because if the access leaves the vein, it can cause phlebitis at the site, or even necrosis. (T16)

I think vital signs should be monitored, when the drug infusion starts, [...] if you have hypertension, if you have fever, you can't start the drug. (T22)

Regarding environmental protection measures:

So, when the patient is there receiving that medication, it is necessary to have hygiene and cleaning personnel and the adequate products to be able to clean. It is already known that the medication the patient takes causes nausea and vomiting: already leave a kidney tank, close to that patient so as not to contaminate the floor, for example. (E4)

I don't know, here, of another place to dispose of these medications. I think there should be a specific place for their disposal. A proper latex for them. (E6)

[...] if there is no orientation and I don't know what can be caused in the patient, in the environment and in the professional, I won't know how to do things, he will say: Ah, it's all garbage, thrown away together with the others! So, there must be orientation. (T7)

Disposal is important for the environment, [...]. Inside the hospital it can't stay in common garbage, no. As for the clothes [...] we have those containers that have less contaminated clothes, more contaminated ones, I think they must be disposed of in one of those, in the container. I don't know the destination after it arrives at the laundry. (T9)

I think that contamination can happen when discarding the materials, there should be a proper place, separate from where they throw the other garbage, other medications, and from other patients. [...] you must put it in a plastic bag and take it to the pharmacy. The destination, they give it to us. (T10)

The cleaning staff must know, also, how to deal with excreta, because they work in sanitation areas that may be contaminated, so the whole hospital needs to be trained. (E16)

I believe that the kind of bottle, which you used for this infusion, must be placed in a coupled, closed place, I don't know, it should not and cannot be in the unit, l imagine it has to be out of place. (T21)

And when it comes to worker protection:

So, the use of PPE is the key in all steps, in the transportation of the drug to the patient, in the administration, and in the disposal. (E6) 
Chart 3 - Nursing professionals' knowledge about patient, environment, and worker protection mechanisms

\begin{tabular}{|c|c|c|c|c|}
\hline Registration Unit & Quantification & $\%$ & Subcategories & Categories \\
\hline \multicolumn{3}{|l|}{ Patient } & \multirow{5}{*}{$\begin{array}{l}\text { Patient protection in } \\
\text { relation to antineoplastic } \\
\text { drugs }\end{array}$} & \multirow{11}{*}{$\begin{array}{l}\text { Nursing professionals' } \\
\text { knowledge about } \\
\text { patient, environment, } \\
\text { and worker protection } \\
\text { mechanisms }\end{array}$} \\
\hline Venous access & \multirow{4}{*}{35} & \multirow{4}{*}{100.00} & & \\
\hline Infection-free environment & & & & \\
\hline Vital signs check & & & & \\
\hline Hygiene of access routes & & & & \\
\hline \multicolumn{3}{|l|}{ Environment } & \multirow{4}{*}{$\begin{array}{l}\text { Care for the } \\
\text { environment in relation } \\
\text { to antineoplastic drugs }\end{array}$} & \\
\hline Dispose of infusion materials in a dedicated container & 28 & 80.00 & & \\
\hline Dispose of infusion materials in plastic bags & 15 & 42.86 & & \\
\hline Dispose of contaminated clothing in plastic bags & 10 & 28.57 & & \\
\hline \multicolumn{3}{|l|}{ Worker } & \multirow{2}{*}{$\begin{array}{l}\text { PPE as a protective } \\
\text { measure }\end{array}$} & \\
\hline Use of PPE & 35 & 100.00 & & \\
\hline
\end{tabular}

For the worker, the use of PPE is fundamental, from preparation to administration and patient care. (T5)

There must be orientation as to the use of a hood, mask, gloves, and to know the effects of the drugs. Because, if there is no orientation and the worker doesn't know what can cause it, he won't know how to do the right things. (T7)

In administration, contamination can occur from a leak in the equipment, or in the disconnection of the equipment from the access, if we are not properly equipped with gloves, mask, the PPE. (T16)

\section{DISCUSSION}

The hospital, site of the study, has a non-specific service for cancer treatment, and it was found that some participants knew the action of antineoplastic drugs to fight malignant cells. However, some professionals revealed that they obtained their knowledge through alternative means and without scientific basis. Knowledge about antineoplastic drugs and their adverse health effects, acquired systematically and based on theories and evidence, is extremely important to increase the adherence of workers to safety and protection measures ${ }^{(10,14)}$.

For the use of antineoplastic drugs in the treatment of cancer and other pathologies to occur safely, it is necessary that professionals have theoretical knowledge and technical skills and that a substantial safety culture is developed so that they understand the process of occupational safety necessary for the handling of these drugs. Without this prior knowledge of risk, it is more difficult to prevent harm ${ }^{(10)}$.

Reports of nurses who cannot solve doubts about the "handling" and administration of antineoplastic drugs revealed the lack of knowledge and unpreparedness of the institution's professionals regarding the handling of these drugs. The fact that nurses use, in their reports, the term "manipulation" instead of "handling" demonstrates the lack of knowledge of these professionals about these drugs. While "manipulation" refers to the preparation of a drug - performed by a pharmacist - "handling" refers to the act of "picking" bottles and materials intended for administration $^{(15)}$, so the latter term is the one that applies to nursing work processes.
Another fact to be highlighted within the problem of handling antineoplastic drugs was the report, by few nurses, of the use of these agents for other pathologies. This data does not correspond to what is expected, especially from these professionals, who have among their attributions the supervision of the nursing team. This issue raises the need for further discussion of these contents in the training of nursing professionals and their articulation with practice, being capital the complementation in graduate courses for specific performance in oncologic care ${ }^{(11)}$.

The lack of knowledge of the study participants about antineoplastic drugs becomes a very worrying issue for workers' health, since the non-identification of the drug exposes professionals, leaving them vulnerable to deleterious effects. From this perspective, it is imperative to consider that the lack of knowledge of HDs by nursing professionals doubly potentializes the exposure of these workers, since the use of these drugs is expanding to other areas of health outside the hospital environment, associated with a considerable number of drugs that are not antineoplastic, but that the National Institute for Occupational Safety and Health (NIOSH) classifies as HD ${ }^{(16-17)}$.

The perception of occupational risks is important to the extent that awareness of them can influence behavior, attitudes, and ways of doing the job safely, avoiding the occurrence of accidents or occupational diseases ${ }^{(18)}$. The speeches of the professionals expressed that they had little experience with antineoplastic drugs, although it could be identified in some aspects, as when they reported that the drugs confer health risk and that it is necessary to use protection to handle them.

It is relevant to highlight that knowledge can be acquired with experience in the work to assist patients who need treatment. However, to assist people who use antineoplastic drugs, the construction of experience is intimately and necessarily linked to the previous knowledge that one has about these drugs - from the names of the drugs and the adequate PPE to the care in their administration, to the side and adverse effects and to the ways in which occupational exposure can occur.

Nursing professionals often begin their work in care services recently graduated and without previous experience. Thus, health institutions, to minimize this issue, in addition to offering training, could determine that newly admitted nurses be accompanied 
by a more experienced professional for a certain period of time, with the goal of providing the experience and skills necessary to perform the job. Generalist training, as recommended by the National Curriculum Guidelines, is a facilitator in many aspects for nursing, because it gives the student a notion of the whole, a glimpse of different realities, and facilitates entry into the job market ${ }^{(11,19)}$. However, not delving into a given knowledge interferes with the acquisition of specific competencies that are necessary to ensure the health and safety of both novice professionals and patients.

The international organizations - more specifically from the United States - that regulate and guide the handling of hazardous waste are concerned about being in accordance with the disclosed guidelines. It is important to point out that divergences may occur due to the legislations being determined by the states, but the standard of the national guidelines released by studies and governmental institutions must be followed. However, a consensus was established: the recommendation disclosed is to manage all antineoplastic drugs as hazardous waste through permitted treatment, storage and disposal facilities ${ }^{(20)}$.

In Brazil, the norms are regulated on a national level by both health surveillance, through ANVISA, and by agencies of the national environmental system. However, state and municipal agencies in these areas can also establish complementary norms at their levels of operation ${ }^{(4)}$. The non-updating of the norms according to international studies and guidelines is an additional factor that influences the higher probability of exposure of professionals and contamination of the healthcare and domestic environments, as well as the soil and water.

Research with nursing teams working in Primary Care also identified gaps in knowledge, attributed to deficits in training and continuing education practices. Despite the time of professional experience, the participants did not consider themselves qualified to care for patients with cancer ${ }^{(21)}$, a fact that is close to the data found in this study, in which $91 \%$ of participants reported not feeling able to handle and administer antineoplastic drugs.

In the sectors researched in the hospital, according to the participants' reports, the materials used in the infusions performed in the patients (gloves, equipment and solution bottles, caps, gases) were stored in large garbage cans with lids, located in the nursing station, where infectious, chemical, and common materials are placed. Similarly, in the nursing station there was the needle box (box for packaging and disposal of sharps from infusions performed on patients), in which the materials were discarded without any separation. This procedure does not provide any protection to the professionals and the environment, since, due to the demand for service, the trash can is open all the time, spreading contamination from the various types of waste stored in it.

A diversity of behaviors regarding the handling of such drugs was reported by the professionals, demonstrating that the actions occur in an isolated manner, within what each professional take for granted. There are no protocols in the institution regarding the procedures to be performed for the care of clothes contaminated by fluids (urine, feces, and vomit) of patients being treated with antineoplastic drugs, to avoid the exposure of professionals and the contamination of the environment. Despite the guidelines and guidance on the care of exposure risks, detectable levels of antineoplastic drugs are still reported in the urine of professionals who handle them, measured by biological monitoring, indicating the permanence of occupational exposure ${ }^{(22)}$.

It is evident that the application of safety norms and guidelines to deal with situations arising from the handling of antineoplastic drugs is essential, emphasizing that the disposal processes must be structured according to the existing norms, and the professional nurse has as important attributions the construction of knowledge and the training and supervision of the team. The consequences of exposure to contamination from the use of antineoplastic drugs can be avoided with the transformation of usual practices, through standardization and training based on work safety and protection of the patient, the worker, and the surrounding environment.

The international standards - NIOSH and United States Pharmacopeia (USP) - are committed to the disclosure of publications on how to control environmental contamination and occupational exposure, which are periodically updated. In Brazil, this culture does not exist, and the institutions that adapt to the international norms are rare, which require engineering control involving structural modifications, as important as the acquisition of specific PPE and permanent education. It is urgent that the international recommendations related to the use of PPE be strictly followed, to offer the greatest possible protection to workers individually. It is forbidden to start any activity related to the handling of antineoplastic drugs in the absence of PPE. They must be evaluated daily as to their conservation and safety conditions, being available and stored in easily accessible places ${ }^{(4,22-23)}$.

A research ${ }^{(24)}$ identified that the drug administration unit was the place where the greatest contamination was found, different from the drug preparation area, which was not expected by the authors because, in the drug handling area, it was supposed that there were high concentrations of drugs. Another factor evidenced was the contamination of places where gloves are not used, such as telephones, computer mouse, and bed in the treatment room. A finding that caught the researchers' attention was the dissemination and contamination of the patient's bathroom, which puts family members and companions at risk, because in many institutions they use the same bathroom.

Thus, the importance of making all workers aware of the potential risks and training them in appropriate safety measures is reinforced. More recent studies have shown that exposure to contamination is widespread in health care facilities, affecting more workers than previously thought ${ }^{(23-24)}$. These transformations in usual practices are based on training and become possible with the availability of equipment and the adoption of adequate conducts to protect the environment.

There are areas of health that require very specific and qualified knowledge, and oncology care ${ }^{(9)}$ and the handling of HDs and their metabolites is one of them, since it involves extensive care with the patient, professional and environment. Until the end of 2018, the regulations for the management of antineoplastic drugs had not been implemented in the institution, the setting of this research, remaining that way until today. For prevention to be effective, it is basic that workers have knowledge about the risks of disease and changes caused by these chemicals. By 
keeping the recommendations updated and training professionals about antineoplastic drugs, it is expected that health professionals, especially those on the nursing staff, will be less vulnerable.

Considering this situation, in order for workers' exposure to antineoplastic drugs to be minimized, investments in permanent education and standardization of routines for all processes involving the handling of antineoplastic drugs are necessary ${ }^{(10)}$.

\section{Study Limitations}

The limitations of this study are the impossibility of generalizations related to the methodological design; the failure to pilot test the interview script; and the non-return of the interviews to the participants for validation. It is suggested, for future research, the inclusion of other members of the multi-professional team (e.g., cleaning professionals) and other points of the care network, for being important areas and sectors for the work and proper handling of antineoplastic drugs.

\section{Contributions to the Area}

The research indicates that the knowledge should be directed to mobilize and sensitize the managers of the institutions as to the responsibilities of all, professionals, and managers, on issues of safety for the worker, the environment, and society. Thus, it is necessary to create a safety culture focused on sharing responsibilities. It was evidenced that the professionals arrive in the labor market with a lack of competencies related to the handling of antineoplastic drugs. Thus, it is essential to incorporate knowledge about the handling of antineoplastic drugs and their implications and care for the maintenance of the worker's health into the training of health professionals. Qualification and in-service training are considered fundamental to minimize the risks in handling these drugs. This study points to continuing education as a possibility in the prevention of accidents and errors, making the performance safer and more effective by minimizing possible complications in the handling of antineoplastic drugs.

\section{FINAL CONSIDERATIONS}

The levels of understanding about antineoplastic drugs and their effects, obtained in the interviews, reaffirm that the participants have some knowledge - often unsubstantiated and inconsistent about the subject, which allows them to have safety behaviors to handle these drugs. However, only knowledge of good practices is not enough to minimize exposure to risk related to these drugs. It was observed the fragility and superficiality of the professionals knowledge and experiences about drugs, besides how they dealt with them, treating them as if they were "common medications". Therefore, the knowledge and experiences reported are not enough to modify their postures in the management of antineoplastic drugs.

Nurses showed little understanding on the subject. Considering that these professionals have, among their functions, to coordinate, train and evaluate the workers that are under their supervision, it was expected that they would demonstrate greater clarity and scientific knowledge in their answers, compared to the other professionals in the study. Thus, they reveal the absence of an educational work, of utmost importance for them to understand the dimension of care needed to deal with antineoplastic drugs.

It is necessary, therefore, that health institutions reorganize their services so that professionals can develop a culture of safety at work, to amplify it not only for the protection of professionals and patients, but also so that workers are able to develop competencies by enhancing and strengthening their experience with antineoplastic drugs.

\section{FUNDING}

This study was financed in part by the Coordenação de Aperfeiçoamento de Pessoal de Nível Superior - Brazil (CAPES) - Finance Code 001.

\section{REFERENCES}

1. Ministério da Saúde (BR), Instituto Nacional de Câncer José Alencar Gomes da Silva (INCA). Estimativa 2020: incidência de câncer no Brasil[Internet]. INCA. Rio de Janeiro: 2019 [cited 2019 Sep 4]. Available from: https://www.inca.gov.br/publicacoes/livros/ estimativa-2020-incidencia-de-cancer-no-brasil

2. Li P, Guo YJ, Tang Q, Yang L. Effectiveness of nursing intervention for increasing hope in patients with cancer: a meta-analysis. Rev Latino-Am Enfermagem. 2018;26:e2937. https://doi.org/10.1590/1518-8345.1920.2937

3. Bonassa EMA, Santana TR. Nursing in cancer therapy. São Paulo: Atheneu; 2005.

4. Ministério da Saúde (BR). Agência Nacional de Vigilância Sanitária (ANVISA). Resolução da Diretoria Colegiada nº. 220, de 21 de setembro de 2004. Aprova o Regulamento Técnico de funcionamento dos Serviços de Terapia Antineoplásica [Internet]. Diário Oficial da União, Brasília (DF): 2004 [cited 2019 Sep 04]. Available from: http://bvsms.saude.gov.br/bvs/saudelegis/anvisa/2004/rdc0220_21_09_2004.html

5. Eisenberg S. USP <800> and strategies to promote hazardous drug safety. J Infus Nurs. 2018;41(1):12-23. https://doi.org/10.1097/ NAN.0000000000000257

6. Connor TH, Lawson CC, Polovich M, McDiarmid MA. Reproductive health risks associated with occupational exposures to antineoplastic drugs in health care settings: a review of the evidence. J Occup Environ Med. 2014;56(9):901-910. https://doi.org/10.1097/ JOM.0000000000000249

7. Villarini M, Gianfredi V, Levorato S, Vannini S, Salvatori T, Moretti M. Occupational exposure to cytostatic/antineoplastic drugs and cytogenetic damage measured using the lymphocyte cytokinesis-block micronucleus assay: a systematic review of the literature and metaanalysis. Mutat Res. 2016;770(PTA):35-45. https://doi.org/10.1016/j.mrrev.2016.05.001 
8. Chini C, Bascialla L, Giaquinto A, Magni E, Gobba SM, Proserpio I, et al. Homcology: home chemotherapy delivery in a simultaneous care project for frail advanced cancer patients. Supp Care Cancer. 2021;29:917-23. https://doi.org/10.1007/s00520-020-05569-9

9. Cogo SB, Reisdorfer AP, Beck JL, Gomes TF, Ilha AG, Leon PB, et al. Nurses and physicians' perception of the care of oncology patients in the emergency department. Rev Bras Enferm. 2020;73(Suppl 6):e20190677. https://doi.org/10.1590/0034-7167-2019-0677

10. Oliveira PP, Santos VEP, Bezerril MS, Andrade FB, Paiva RM, Silveira EAA. Patient safety in the administration of antineoplastic chemotherapy and of immunotherapics for oncological treatment: scoping review. Texto Contexto Enferm. 2019;28:e20180312. https://doi. org/10.1590/1980-265X-TCE-2018-0312

11. Souza NR, Bushatsky M, Figueiredo EG, Melo JTS, Freire DA, Santos ICRV. Oncological emergency: the work of nurses in the extravasation of antineoplastic chemotherapeutic drugs. Esc Anna Nery. 2017;21(1):e20170009. https://doi.org/10.5935/1414-8145.20170009

12. Cruz EDA, Rocha DJM, Maurício AB, Ulbrich FS, Batista J, Maziero ECS. Safety culture among health professionals in a teaching hospital. Cogitare Enferm. 2018;23(1):e50717. https://doi.org/10.5380/ce.v23i1.50717

13. Bardin L. Análise de Conteúdo. Coimbra: Edições 70; 2011.

14. Alehashem M, Baniasadi S. Important exposure controls for protection against antineoplastic agents: highlights for oncology health care workers. Work. 2018;59(1):165-72. https://doi.org/10.3233/wor-172656

15. Conselho Regional de Farmácia do Estado do Paraná. Farmácia com Manipulação: guia da profissão farmacêutica [Internet]. Curitiba: 2017 [cited 2021 Mar 10]. Available from: https://www.crfpr.org.br/uploads/revista/28746/aZZf464JBFpB_j0DtYTwkQy0BI3URohA.pdf

16. Crickman R. Chemotherapy safe handling: limiting nursing exposure with a hazardous drug control program. Clin J Oncol Nurs. 2017;21(1):73-8. https://doi.org/10.1188/17.CJON.73-78

17. Department of Health and Human Services (US). National Institute for Occupational Safety and Health (NIOSH). NIOSH list of antineoplastic and other hazardous drugs in healthcare settings [Internet]. Cincinnati: 2016 [cited 2018 Nov 10]. Available from: https://www.cdc.gov/ niosh/docs/2016-161/pdfs/2016-161.pdf?id=10.26616/NIOSHPUB2016161

18. Luize PB, Canini SRMS, Gir E, Toffano SEM. Procedures after exposure to biological material in a specialized cancer hospital. Texto Contexto Enferm. 2015;24(1):170-7. https://doi.org/10.1590/0104-07072015002700013

19. Galindo I, Kempfer S, Romanoski P, Lazzari D, Bresolin P, Gorris P. Intensivist nursing: process of professional qualification. Rev Enferm UFSM. 2019;9(e49):1-20. https://doi.org/10.5902/2179769234763

20. United States Environmental Protection Agency (USEPA). Laws \& Regulations: collections and lists [Internet]. Washington: 2019 [cited 2018 Jan 05]. Available from: https://www.epa.gov/laws-regulations

21. Rosa LM, Souza AIJ, Anders JC, Silva RN, Silva GS, Fontão MC. Oncology nursing care and qualification demands in primary health care. Cogitare Enferm. 2017;22(4):e51607. https://doi.org/10.5380/ce.v22i4.51607

22. United States Department of Labor (US). Occupational Health and Safety Administration (OSHA). OSHA Tecnical Manual [Internet]. Washington: 2016 [cited 2018 Oct 05]. Available from: https://www.osha.gov/SLTC/hazardousdrugs/controlling_occex_hazardousdrugs.html

23. The United States Pharmacopeial Convention (USP). General Chapter 800 hazardous drugs: handling in healthcare settings [Internet]. North Bethesda: 2017 [cited 2018 Nov 20]. Available from: https://www.usp.org/sites/default/files/usp/document/our-work/healthcare-qualitysafety/general-chapter-800.pdf

24. Viegas S, Oliveira AC, Carolino E, Pádua M. Occupational exposure to cytotoxic drugs: the importance of surface cleaning to prevent or minimise exposure. Arh Hig Rada Toksikol. 2018;69(3):238-49. https://doi.org/10.2478/aiht-2018-69-3137 